\title{
Case for diagnosis. Multinucleated cell angiohistiocytoma*
}

\author{
Margarida Rato ${ }^{1}$ \\ Joana Parente ${ }^{1}$
}

DOI: http://dx.doi.org/10.1590/abd1806-4841.20186821

\author{
Ana Filipe Monteiro ${ }^{1}$ \\ João Aranha ${ }^{1}$
}

\section{CASE REPORT}

We report a healthy 60-year-old woman who presented with multiple asymptomatic, erythematous lesions scattered over the face, with progressive appearance over the last year. Objective examination revealed erythematous, non-desquamative papules with firm consistency and relatively well-defined borders, measuring 5-10 mm, located in both malar regions (Figures 1 and 2). A biopsy of one of the lesions was performed. Histopathological examination revealed multinucleated cells of varying dimensions in the superficial dermis characterized by angular outlines, mainly showing a ring arrangement in the periphery. Vimentine staining (not CD68) revealed proliferation of small-dilated vessels (FVIIIand vimentin-positive endothelial cells), interstitial infiltrate of dendritic cells (positive for FXIIIa and vimentin), and perivascular lymphohistiocytic infiltrate (Figures 3 and 4). Clinical and histopathological findings favored the diagnosis of multinucleated cell angiohistiocytoma. Given the benign nature of this entity, the patient refused treatment.

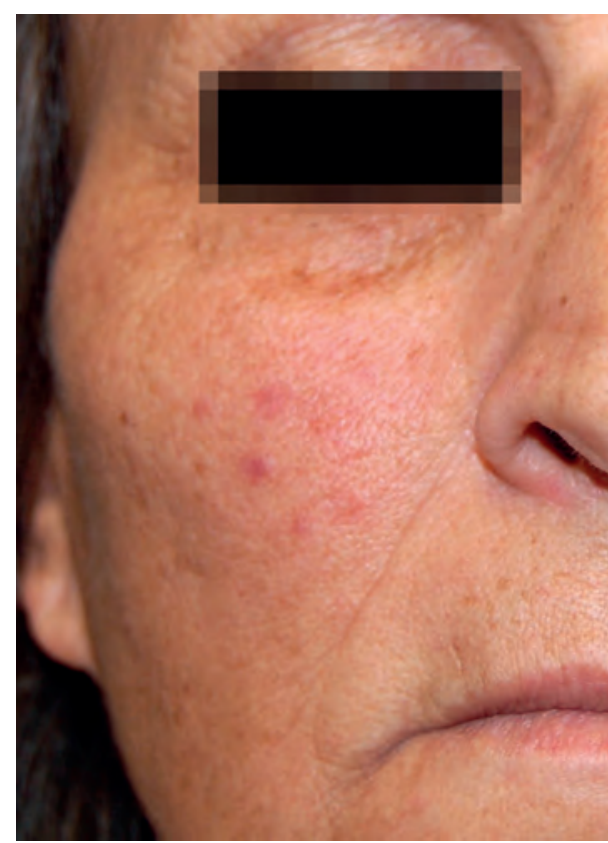

FIGURE 1: Erythematous papules in the right malar region

Received on 15.12.2016.

Approved by the Advisory Board and accepted for publication on 30.04.2017.

* Work performed at the Dermatology Service of the Hospital de Santarém EPE - Santarém, Portugal.

Financial support: None.

Conflict of interest: None.

1 Dermatology Service at Hospital de Santarém EPE - Santarém, Portugal.

MAILING ADDRESS:

Margarida Pinheiro Gaio Seabra Rato

E-mail: margaridagaiorato@gmail.com 


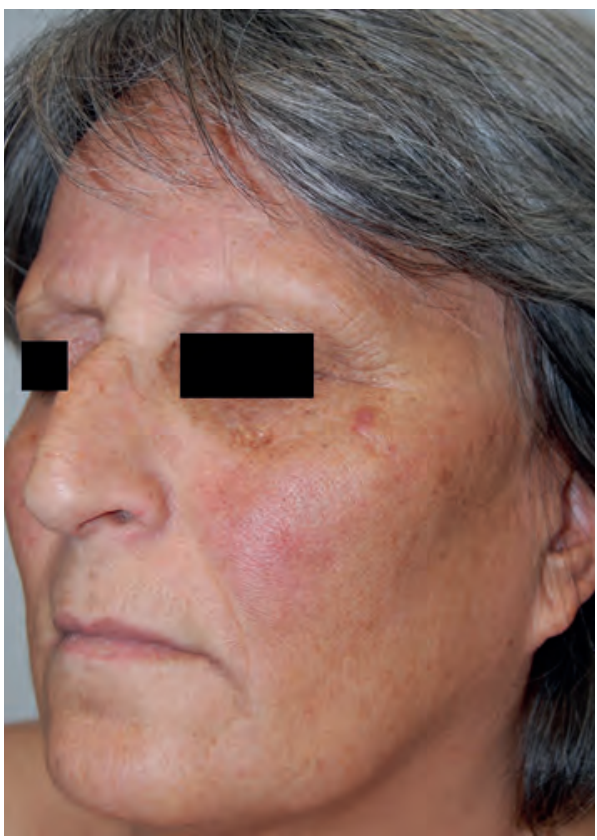

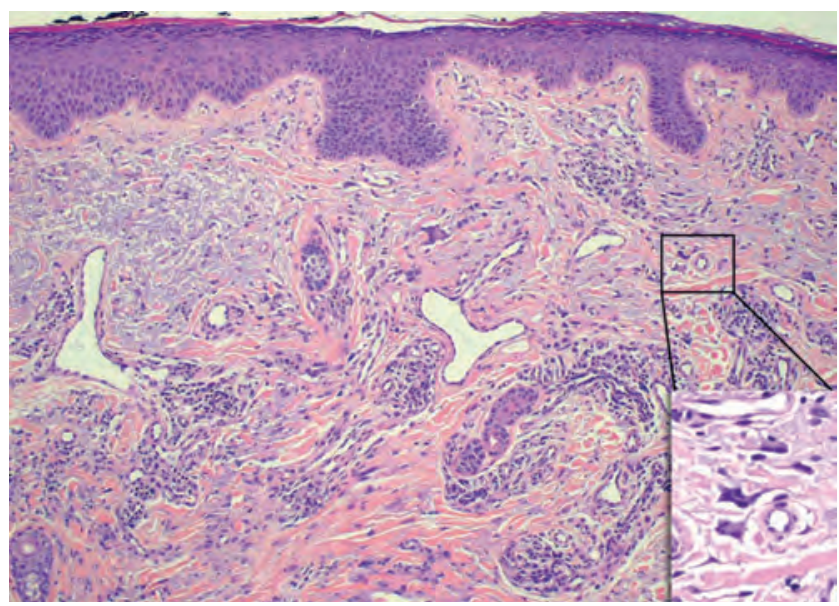

FIGURE 3: Multinucleated cells in the superficial dermis with an angular outline (detailed in lower right corner, Hematoxylin \& eosin, X100). Proliferation of small dilated vessels, slight interstitial infiltrate of spindle or dendritic perivascular cells, mostly lymphohistiocytic (Hematoxylin \& eosin, X40)

FIGURE 2: Non-desquamative erythematous papule in the left malar region with well-defined limits
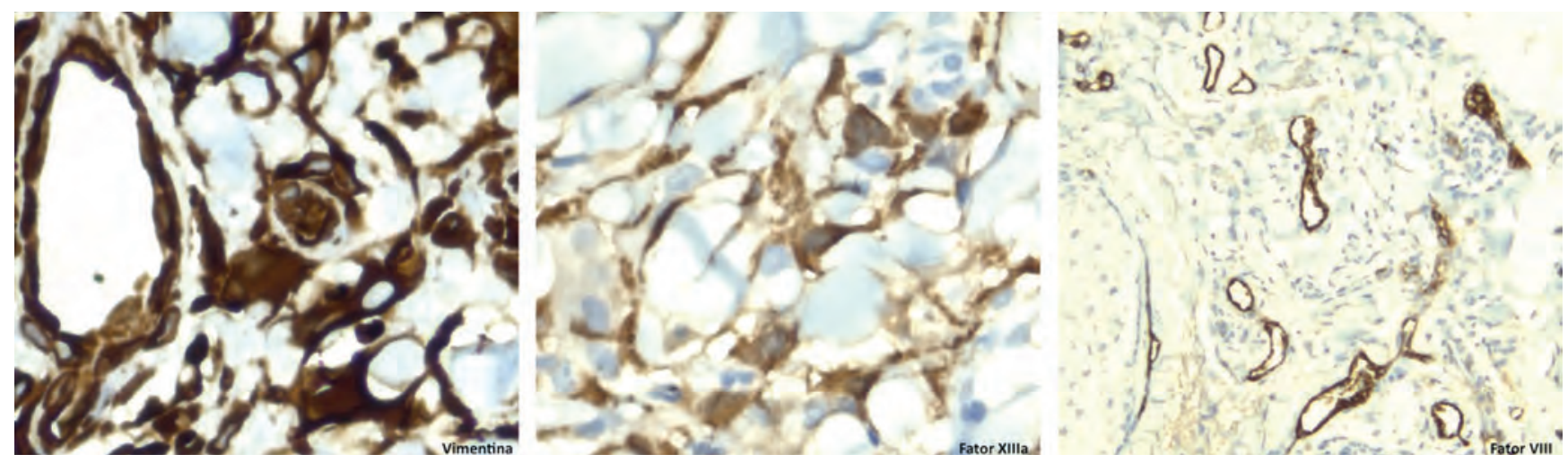

FigURE 4: On the left, staining of endothelial, dendritic, and multinucleated cells by vimentin (magnification X400). In the center, staining of dendritic cells by factor XIIIa (magnification X400). On the right, endothelial cell staining by factor VIII (magnification X100)

\section{DISCUSSION}

Multinucleated cell angiohistiocytoma (MCA), first described in 1985 by Smith and Wilson-Jones, is a rare benign vascular and fibrohistiocytic proliferation, which occurs most often in women between 40 and 70 years of age. ${ }^{1-5}$ It usually manifests itself as asymptomatic grouped papules, red-brownish to violaceous in color, of indolent appearance and progressive growth, usually located on the dorsum of the hands or on the legs. ${ }^{2-5}$

The pathogenesis of MCA remains unknown, but the current evidence points to a reactive process..$^{3-6}$ It appears to be an underdiagnosed entity with less than 150 cases reported in the literature. ${ }^{6}$

Histopathologically, MCA is characterized by vascular hyperplasia associated with an increased number of factor XIIIa-pos- itive fibrohistiocytic interstitial cells and multinucleated cells with angular contours located in the dermis. ${ }^{3,7}$ Although not pathognomonic of MCA, the presence of multinucleated giant cells is the most specific histopathological finding (3-10 hyperchromatic nuclei and basophilic cytoplasm) ${ }^{7,8}$ In a immunohistochemical study, multinucleated cells are stained by vimentin and, alternatively, by CD68. Mononuclear dendritic cells are positive for vimentin, factor XIIIa, MAC387, and lysozyme. Endothelial cells, in turn, are positive for vimentin, CD31, CD34, and factor VIII. 3,4,9

In the present case, the differential diagnosis with fibrous papule of the face/angiofibroma is particularly prominent. Clinically, these diagnoses are less likely, since the fibrous papules 
appear as isolated skin-color lesions and angiofibromas, ususally associated with other syndromes. These lesions are exophytic with harder consistency and well-defined limits. Histologically, although MCA, angiofibroma, and fibrous papule exhibit common characteristics of dilated capillaries in the dermis, in the latter two, the collagen bundles show a vertical or perifollicular orientation (unlike the horizontal orientation observed in MCA) with only a few multinucleated cells. ${ }^{3,7,10}$
Although MCA follows a slowly progressive course, rare cases of spontaneous regression are described in the literature, for which a conservative approach is recommended..$^{3-5}$

MCA is a distinct clinical-pathological entity that should be considered in the differential diagnosis of other vascular and fibrohistiocytic proliferations. The present case revealed a less frequent location of this pathology that may impose some difficulties in its diagnosis.

\begin{abstract}
Multinucleate cell angiohistiocytoma is a rare idiopathic benign fibrohistiocytic and vascular proliferation usually presenting as multiple asymptomatic papules, red to violaceous in colour, primarily located on the extremities of middle-aged females. This entity is probably underdiagnosed due to the lack of recognition by clinicians and pathologists. We describe a patient with a multinucleate cell angiohistiocytoma of the face, a less frequent localization, in order to increase awareness of this entity and elucidate its clinical, histopathological, and immunohistochemistry features.
\end{abstract}

Keywords: Facial dermatoses; Giant Cells; Neoplasms, vascular tissue

\section{REFERENCES}

1. Smith NP, Wilson Jones E. Multinucleate cell angiohistiocytoma: a new entity. $\mathrm{Br}$ J Dermatol. 1985;113:15.

2. Teixeira V, Serra D, Pereira N, Tellechea 0. Multinucleate cell angiohistiocytoma: a new case report with dermoscopy. Dermatol Online J. 2014;20 pii.

3. Applebaum DS, Shuja F, Hicks L, Cockerell C, Hsu S. Multinucleate cell angiohistiocytoma: a case report and review of the literature. Dermatol Online J. 2014;20:22610.

4. Chu JN, Brown RA, Kim J, Pol-Rodriguez MM. Mildly pruritic violaceous papules on the dorsum of the left hand. Clin Exp Dermatol. 2015;40:580-2.

5. Pérez LP, Zulaica A, Rodríguez L, Campo MC, Peñaranda JM, Fernández-Redondo V, et al. Multinucleate cell angiohistiocytoma. Report of five cases. J Cutan Pathol. 2006;33:349-52.
6. Frew JW. Multinucleate cell angiohistiocytoma: clinicopathological correlation of 142 cases with insights into etiology and pathogenesis. Am J Dermatopathol. 2015;37:222-8.

7. Blanco Barrios S, Rodríguez Díaz E, Alvarez Cuesta C, Galache Osuna C, Requena Caballero C, Martínez Merino A, et al. Multinucleate cell angiohistiocytoma: a new case report. J Eur Acad Dermatol Venereol. 2005;19:208-11.

8. Väkevä L, Saksela 0, Kariniemi AL. Multinucleate cell angiohistiocytoma: a report of four cases in Finland. Acta Derm Venereol. 2003;83:222-3.

9. Pérez LP, Zulaica A, Rodríguez L, Campo MC, Peñaranda JM, Fernández-Redondo $\mathrm{V}$, et al. Multinucleate cell angiohistiocytoma. Report of five cases. J Cutan Pathol. 2006:33:349-52.

10. Jaconelli L, Kanitakis J, Ktiouet S, Faure M, Claudy A. Multinucleate cell angiohistiocytoma: report of three new cases and literature review. Dermatol Online J. 2009;15:4.

How to cite this article: Rato M, Monteiro AF, Parente J, Aranha J. Case for diagnosis. Multinucleated cell angiohistiocytoma. An Bras Dermatol. 2018;93(2):291-3. 